Creative commons User License: CC BY-NC-ND

Abstracted by: EBSCOhost, Electronic Journals Service (EJS),

Google Scholar, Directory of Open Access Journals (DOAJ),

Journal Seek, Scientific Commons,

Food and Agricultural Organization (FAO), CABI and Scopus
Journal of Agricultural Extension

Vol. XX (X) XXXXXX, 20XX

ISSN(e): 24086851; ISSN(Print); 1119944X

http://journal.aesonnigeria.org

http://www.ajol.info/index.php/jae

Email: editorinchief@aesonnigeria.org

\title{
Differences in Knowledge of Climate Change between Male and Female Livestock Farmers in Nsukka Agricultural Zone of Enugu State, Nigeria http://dx.doi.org/10.4314/jae.v20i2.17
}

\section{Chah, J.M.}

Department of Agricultural Extension, Faculty of Agriculture, University of Nigeria, Nsukka

jane.chah@unn.edu.ng

$+2348032420600$

Uddin, I.O.

Department of Agricultural Extension, Faculty of Agriculture, University of Nigeria, Nsukka uddinirenonsen@gmail.com $+2347036842083$

Odo, E. M.

Department of Agricultural Extension, Faculty of Agriculture, University of Nigeria, Nsukka $+2348064137900$

\section{Abstract}

This study identified gender differences in knowledge of climate change among livestock farmers in Nsukka agricultural zone, Enugu State. Data were collected using a multistage sampling technique to select 80 livestock farmers. Percentage, mean statistics and standard deviation were used in the presentation of the results. Hypothesis for the study was analysed using t-test. The results showed that the mean age of respondents was 49 years and 31.2 percent of farmers had secondary school education. Both male (50 percent) and female (55 percent) respondents had medium knowledge on climate change as it relates to livestock production. The major information sourced by male and female respondents was on where to sell their livestock $(97.1 \%$ and $100.0 \%)$. There was no significant difference between men $(M=13.92 ; t=$ $0.971)$ and women's ( $M=13.20 ; t=0.971)$ knowledge on climate change with respect to livestock production. Campaigns should be intensified to sustain and improve existing knowledge on climate change among male and female livestock producers in the study area.

Keywords: Gender, climate change, knowledge, livestock production. 
Creative commons User License: CC BY-NC-ND

Abstracted by: EBSCOhost, Electronic Journals Service (EJS),

Google Scholar, Directory of Open Access Journals (DOAJ),

Journal Seek, Scientific Commons,

Food and Agricultural Organization (FAO), CABI and Scopus
Journal of Agricultural Extension

Vol. XX (X) XXXXXX, 20XX

ISSN(e): 24086851; ISSN(Print); 1119944X

http://journal.aesonnigeria.org

http://www.ajol.info/index.php/jae

Email: editorinchief@aesonnigeria.org

\section{Introduction}

Agriculture, primarily small scale, is one of the most important sectors of the Nigerian economy. Agriculture accounts for about $24.18 \%$ of Nigeria's Gross Domestic Product (GDP) and $70 \%$ of informal sector jobs created in the economy are related to rural agriculture (Enejeta, 2016). Livestock accounts for one third of Nigeria's agricultural GDP (Nwagwu \& Soremi, 2015), providing income, employment, food, farm energy, manure, fuel and transport. They are also a major source of government revenue. Livestock especially ruminants, are the most efficient users of uncultivated land and can contribute substantially to crop production. This implies that agriculture is a key sector that stands to affect then majority of Nigerians positively (Okolo, 2004).

Climate change is a major threat to agricultural production especially livestock (Anyadike, 2009), mainly arising from its impact on grassland and productivity. Heat stress suffered by animals will reduce the rate of animal feed intake and result in poor growth performance (Rowlinson, 2008). Lack of water and increase frequency of drought in certain countries will lead to loss of resources. Consequently, as exemplified by many African countries, existing food insecurity and conflict over scarce of resources will be exacerbated (Calvosa, 2009).

Ozor (2009) stated that livestock production systems in Nigeria would be vulnerable to climate change in respect of anticipated decrease in rainfall in the Sudan-sahelian zone and consequent reduction in the available pastureland. This is to say that further changes in rainfall and temperature will affect livestock production as well as availability of animal species. Though increase in temperature is generally seen to be destructive to the production of crops and human lives, FAO (2009) noted that livestock production could be boosted by temperature increase. Conversely, Deressa and Hassan (2009) found increasing temperature damaging to Nigerian agriculture; a situation that is not uniformly distributed across agro-ecological zones. Issa (2009) in agreement with the findings of Deressa and Hassan (2009) reported that both commercial and subsistence livestock farmers are negatively affected by rising 
Creative commons User License: CC BY-NC-ND

Abstracted by: EBSCOhost, Electronic Journals Service (EJS),

Google Scholar, Directory of Open Access Journals (DOAJ),

Journal Seek, Scientific Commons,

Food and Agricultural Organization (FAO), CABI and Scopus
Journal of Agricultural Extension

Vol. XX (X) XXXXXX, 20XX

ISSN(e): 24086851; ISSN(Print); 1119944X

http://journal.aesonnigeria.org

http://www.ajol.info/index.php/jae

Email: editorinchief@aesonnigeria.org

temperature. According to Tailor and Negada (2005), heat stress had detrimental effect on the reproduction of buffaloes. Upadhya et al (2009) also stated that thermal stress on Indian livestock particularly cattle and buffaloes has been reported to decrease estrus expression and conception rate. This implies that varying climate has varying effects on crops and livestock depending on the agro-ecological location. This shows that farmers need to have a good knowledge of climate change.

According to Smith, (2007) knowledge is the process of attaining awareness or understanding of the environment by organizing and interpreting sensory information. It is the process by which information or stimuli are received from the environment and transformed into psychological awareness; information about climate change is a crucial component of adaptation. It is important to ensure that knowledge is shared with local communities. An understanding of patterns of variability of current and projected climate and seasonal forecast is essential in anticipating shocks and losses, and in enabling external agencies to provide targeted assistance to local communities and indigenous people have an in-depth understanding of their environmental and vast experience in adapting to climate change variability. This knowledge is key to the development of effective adaptation and mitigation strategies to climate change effect. The impact of climate change will be felt by countries, communities and people differently based on the extent of their vulnerability (Ozor, 2010). Gender is a very critical aspect of all development initiatives such as agriculture and climate change in particular (Issa, Tologbonse, Olaleye, Tologbonse \& Kagbu, 2015). Men, women (especially), the elderly youth and children will experience the impacts of climate change differently (Egbule, 2014). Women are particularly growing to be more vulnerable not because of their sex but because of the social, cultural and economic roles they perform. They constitute the majority of poor people due to lack of access to some agricultural resources.

Women's traditional roles include being the primary users and managers of natural resource, primary care givers and labourers engaged in unpaid labour. However, women lack rights and access to resources and information vital to overcoming the challenge posed by climate change (http://ww.undp.org/climatechange/adapt/basic3html). If a gender approach is not 
Creative commons User License: CC BY-NC-ND

Abstracted by: EBSCOhost, Electronic Journals Service (EJS),

Google Scholar, Directory of Open Access Journals (DOAJ),

Journal Seek, Scientific Commons,

Food and Agricultural Organization (FAO), CABI and Scopus
Journal of Agricultural Extension

Vol. XX (X) XXXXXX, 20XX

ISSN(e): 24086851; ISSN(Print); 1119944X

http://journal.aesonnigeria.org

http://www.ajol.info/index.php/jae

Email: editorinchief@aesonnigeria.org

considered in the design and development measures to climate change, the differences between women, men and youth will be overlooked thereby inadvertently reinforcing gender inequality. It is therefore necessary to determine gender differences in the knowledge of climate change in livestock production in Nsukka Agricultural Zone of Enugu State, Nigeria. The study specifically sought to describe the socio-economic characteristics of respondents; identify gender differences in knowledge of climate change on livestock production; ascertain the extent to which information sources on climate change are used; and identify gender differences on information sourced on climate change.

Ho1: There is no significant difference between men and women's knowledge of climate change to livestock production.

\section{Methodology}

The population for the study comprised of all livestock farmers in Nsukka Agricultural Zone in Enugu State, Nigeria. Multistage sampling technique was used in selecting respondents for the study. In the first stage, two blocks were selected out of the three blocks in Nsukka Agricultural Zone. In the second stage, four circles (Obukpa, Ibagwa-ani, Edem-ani, Okpuje, Eha-alumona, Alo-uno, Nru, Nguru) were selected from each of the selected blocks. In the third stage, with the help of the zonal extension officer and the head of the department of agriculture in the LGAs, a list of livestock farmers was compiled. From the list, 10 farmers were selected from each circle using simple random sampling techniques to give a total of 80 farmers for the study.

Data for the study were collected using structured interview schedule. Socioeconomic characteristics were measured as follows: age, sex, marital status, farming experience, educational level, membership of social organization, household size, major livestock and extension visit.

To determine gender differences in knowledge of climate change, relevant knowledge questions were drawn. Respondents were asked to tick yes or no to assess their knowledge level by responding to thirty (30) open and closed 
Creative commons User License: CC BY-NC-ND

Abstracted by: EBSCOhost, Electronic Journals Service (EJS),

Google Scholar, Directory of Open Access Journals (DOAJ),

Journal Seek, Scientific Commons,

Food and Agricultural Organization (FAO), CABI and Scopus
Journal of Agricultural Extension

Vol. XX (X) XXXXXX, 20XX

ISSN(e): 24086851; ISSN(Print); 1119944X

http://journal.aesonnigeria.org

http://www.ajol.info/index.php/jae

Email: editorinchief@aesonnigeria.org

(structured) questions. Each correct answer had one point. The highest score was 30 points and the lowest was zero (0). The respondents were thereafter categorized into three (3) groups based on their knowledge level namely; low knowledge (for those respondents with 1-10 score), medium knowledge (for those respondents with 11-20 score) and high knowledge (for those respondents with 21-30 score).

A three point Likert-type scale of to a great extent (3), to a little extent (2) and to no extent (1) was used to ascertain the extent to which information sources on climate change was used as it relates to livestock production. The values were added up to get 6 which were later divided by 3 to get 2 (mean). Variables with mean values of 2 and above were regarded as sources effectively used by respondents to source information on climate change with respect to livestock production while those with mean values less than 2 were not effectively used. Also, the type of information sourced for was ascertained by providing a list of options for respondents to tick from.

\section{Results and Discussion}

\section{Socio-economic characteristics of livestock producers}

Table 1 reveals that the majority $(60.0 \%)$ of the respondents were within the age bracket of 41 years and above while small proportion (6.2\%) was less than 20 years of age. The mean age of the farmers was 49 years. This implies that the respondents were still within active and productive ages and can be efficient in livestock production. Furthermore, it suggests that they have sufficient knowledge and experience pertaining to their environment and would be able to give vital information regarding climate change. Younger farmers have been found to be more knowledgeable about new practices and may be more willing to bear the risks of adopting a new technology (Olaniyi and Rafiu, 2005). The majority (75.0\%) of the farmers were married, while $10.0 \%$ of the farmers were widowed. This indicates that there were more of married livestock farmers in Nsukka Agricultural Zone in Enugu State and this could provide these livestock farmers with a commensurate supply of family labour, which is cheaper and readily available. Marriage encourages 
Creative commons User License: CC BY-NC-ND

Abstracted by: EBSCOhost, Electronic Journals Service (EJS), Google Scholar, Directory of Open Access Journals (DOAJ), Journal Seek, Scientific Commons,

Food and Agricultural Organization (FAO), CABI and Scopus
Journal of Agricultural Extension

Vol. XX (X) XXXXXX, 20XX

ISSN(e): 24086851; ISSN(Print); 1119944X

http://journal.aesonnigeria.org

http://www.ajol.info/index.php/jae

Email: editorinchief@aesonnigeria.org

complementarities of efforts among farming households (Nnadi et al., 2012). Table 1 shows that $86.2 \%$ of the farmers have been in livestock production from 1 to 10 years while $5.0 \%$ has been in it for 21 years and above. The period is enough for the farmers to observe the effects of the changing climate. According to IPCC (2007), any change should be observed for at least one decade before it could be said to be climate change. 
Creative commons User License: CC BY-NC-ND

Abstracted by: EBSCOhost, Electronic Journals Service (EJS), Google Scholar, Directory of Open Access Journals (DOAJ), Journal Seek, Scientific Commons,

Food and Agricultural Organization (FAO), CABI and Scopus
Journal of Agricultural Extension

Vol. XX (X) XXXXXX, 20XX

ISSN(e): 24086851; ISSN(Print); 1119944X

http://journal.aesonnigeria.org

http://www.ajol.info/index.php/jae

Email: editorinchief@aesonnigeria.org

Table 1: Socioeconomic characteristics of respondents

\begin{tabular}{|c|c|c|}
\hline Variable & Percentage (\%) & Mean (M) \\
\hline \multicolumn{3}{|l|}{ Age (Years) } \\
\hline Less than 20 & 6.2 & \\
\hline $21-25$ & 6.2 & \\
\hline $26-30$ & 7.5 & 48.9 \\
\hline $31-35$ & 12.5 & \\
\hline $36-40$ & 7.5 & \\
\hline 41 and above & 60.0 & \\
\hline \multicolumn{3}{|l|}{ Sex } \\
\hline Male & 50.0 & \\
\hline Female & 50.0 & \\
\hline \multicolumn{3}{|l|}{ Marital Status } \\
\hline Single & 15.0 & \\
\hline Married & 75.0 & \\
\hline Widowed & 10.0 & \\
\hline Divorced & - & \\
\hline \multicolumn{3}{|l|}{ Farming Experience (Years) } \\
\hline $1-10$ & 86.2 & \\
\hline $11-20$ & 8.8 & \\
\hline 21 and above & 5.0 & 11.9 \\
\hline \multicolumn{3}{|l|}{ Educational Level } \\
\hline No formal education & 16.2 & \\
\hline Primary school attempted & 13.8 & \\
\hline Primary school completed & 26.2 & \\
\hline Secondary school attempted & 6.2 & \\
\hline Secondary school completed & 31.2 & \\
\hline Tertiary education & 6.2 & \\
\hline \multicolumn{3}{|c|}{ Membership of Social Organization } \\
\hline Yes & 72.3 & \\
\hline No & 27.7 & \\
\hline \multicolumn{3}{|l|}{ Household Size } \\
\hline $1-5$ & 43.8 & \\
\hline $6-10$ & 52.5 & \\
\hline More than 10 persons & 3.8 & \\
\hline \multicolumn{3}{|l|}{ Major livestock kept } \\
\hline Goat & 52.5 & \\
\hline Sheep & 1.2 & \\
\hline Poultry & 21.2 & \\
\hline Pig & 22.2 & \\
\hline Cattle & 2.4 & \\
\hline
\end{tabular}

Source: Field survey, 2014

It was seen that $26.2 \%$ of them had primary school education, $31.2 \%$ of them got up to secondary level, and $16.2 \%$ did not attend any formal school while $6.2 \%$ attended tertiary institution. This therefore implies that a higher number of farmers in the area 
Creative commons User License: CC BY-NC-ND

Abstracted by: EBSCOhost, Electronic Journals Service (EJS),

Google Scholar, Directory of Open Access Journals (DOAJ),

Journal Seek, Scientific Commons,

Food and Agricultural Organization (FAO), CABI and Scopus
Journal of Agricultural Extension

Vol. XX (X) XXXXXX, 20XX

ISSN(e): 24086851; ISSN(Print); 1119944X

http://journal.aesonnigeria.org

http://www.ajol.info/index.php/jae

Email: editorinchief@aesonnigeria.org

were educated though the level of literacy differed. The acquisition of formal education will increase the receipt of information on climate change, leading to a broader knowledge of it (Ozor et al., 2015). According to Agbamu (2008), the acquisition of formal education promotes the adoption of improved agricultural technologies. Again $72.3 \%$ of the farmers belonged to social organizations. This implies that the farmers are likely to get information about climate change from their fellow members. Table 1 further shows that the majority of the farmers $(52.5 \%)$ maintained a family (household) of 6 to 10 (or average mean of 5 ) people, $43.8 \%$ have household member of 1 to 5 while $3.8 \%$ of the farmers had a household size of $3.8 \%$. The implication for the household size of between 6 and 10 people is that there will be more hands to help in agricultural activities and also house works. Furthermore, $52.5 \%$ of the farmers reared goat, $22.2 \%$ of them reared pig, and $21.2 \%$ reared sheep. From this, it is obvious that the majority of the farmers in the study area were more into goat production. Globally, livestock contributes about $40 \%$ to the agricultural GDP and constitutes about 30\% to the agricultural GDP of developing countries (World Bank, 2009). Hence the participation of farmers in livestock rearing will boost the local economy of the study area.

\section{Gender differences in knowledge of climate change on livestock production}

Male $(92.1 \%)$ and female $(86.8 \%)$ respondents scored high on climate change matters bordering on excessive heat (Table 2), water scarcity (male 86.8\%, female $89.5 \%$ ) and high incidence of disease outbreak (male $81.6 \%$, female $81.6 \%$ ). Nonetheless, male farmers were more knowledgeable than the female on climate change related matters on the subject of high incidence of drought (male $78.9 \%$, female $57.9 \%$ ) and drying up of pastureland (male $78.9 \%$, female 52.6\%). However, both male and female respondents were not knowledgeable about the impact of climate change on humidity, rainfall duration and wind intensity.

The cumulative effect of these dynamics is that men and women differ, on average, in their knowledge and perceptions of climate change. Hence efforts should be made to develop programmes or training that best suit their peculiarities. 
Creative commons User License: CC BY-NC-ND

Abstracted by: EBSCOhost, Electronic Journals Service (EJS),

Google Scholar, Directory of Open Access Journals (DOAJ),

Journal Seek, Scientific Commons,

Food and Agricultural Organization (FAO), CABI and Scopus
Journal of Agricultural Extension

Vol. XX (X) XXXXXX, 20XX

ISSN(e): 24086851; ISSN(Print); 1119944X

http://journal.aesonnigeria.org

http://www.ajol.info/index.php/jae

Email: editorinchief@aesonnigeria.org

Table 2: Gender differences in knowledge score of climate change on livestock production

\begin{tabular}{llll}
\hline \multirow{2}{*}{ Knowledge items } & Male & Female & Pooled \\
\cline { 2 - 4 } & $\begin{array}{l}\text { Right } \\
\text { answer } \\
\text { (\%) }\end{array}$ & $\begin{array}{l}\text { Right } \\
\text { answer } \\
\text { (\%) }\end{array}$ & $\begin{array}{l}\text { Right answer } \\
\text { (\%) } \mathbf{n}=\mathbf{7 6}\end{array}$ \\
\hline Excessive heat & 92.1 & 86.8 & 89.5 \\
Water scarcity & 86.8 & 89.5 & 88.2 \\
High incidence of disease outbreak & 81.6 & 81.6 & 81.6 \\
High mortality rates as a result of climate change & 81.6 & 81.6 & 81.6 \\
Abnormal rise in temperature & 81.6 & 78.9 & 80.3 \\
Increase in rainfall intensity/heavy rain & 76.3 & 81.6 & 78.9 \\
Intense sunlight & 78.9 & 76.3 & 77.6 \\
Drying of water bodies & 81.6 & 73.7 & 77.6 \\
Irregular noise of animal due to heat stress & 78.9 & 71.1 & 75.0 \\
High incidence of disease pest and disease & 71.1 & 76.3 & 73.7 \\
High incidence of drought & 78.9 & 57.9 & 68.4 \\
Drying up of pastureland as a result of climate & 78.9 & 52.6 & 65.8 \\
Low humidity & 44.7 & 39.5 & 42.1 \\
High humidity & 34.2 & 42.1 & 38.2 \\
Short rainfall duration & 50.0 & 21.1 & 35.5 \\
Short period of harmattan & 36.8 & 31.6 & 34.2 \\
Long period of harmattan & 44.7 & 18.4 & 31.6 \\
Long rainfall duration & 36.8 & 21.1 & 28.9 \\
High wind intensity & 21.1 & 34.2 & 27.6 \\
Panting of the animal as a result of climate change & 18.4 & 23.7 & 21.1 \\
\hline
\end{tabular}

Data in Figure 1 show that both male (50\%) and female (55\%) had medium knowledge about climate change. A greater proportion of male (47.5\%) and female (40\%) knew a lot about climate change. This implies that farmers in the area are knowledgeable about climate change though their knowledge level differed. The capacity of farmers to effectively understand trends in climate change can be significantly influenced by the level of knowledge they have on climate change related issues. However, the limited knowledge about climate change among some farmers could also be as a result of their inability to access scientific information on climate change which could be attributed to inadequate number of extension staff in the area (Onyeneke and Madukwe, 2008). This may hamper their ability to adapt to climate change thus leading to poor agricultural harvests (Ozor et al., 2015). 
Creative commons User License: CC BY-NC-ND

Abstracted by: EBSCOhost, Electronic Journals Service (EJS),

Google Scholar, Directory of Open Access Journals (DOAJ),

Journal Seek, Scientific Commons,

Food and Agricultural Organization (FAO), CABI and Scopus
Journal of Agricultural Extension

Vol. XX (X) XXXXXX, 20XX

ISSN(e): 24086851; ISSN(Print); 1119944X

http://journal.aesonnigeria.org

http://www.ajol.info/index.php/jae

Email: editorinchief@aesonnigeria.org

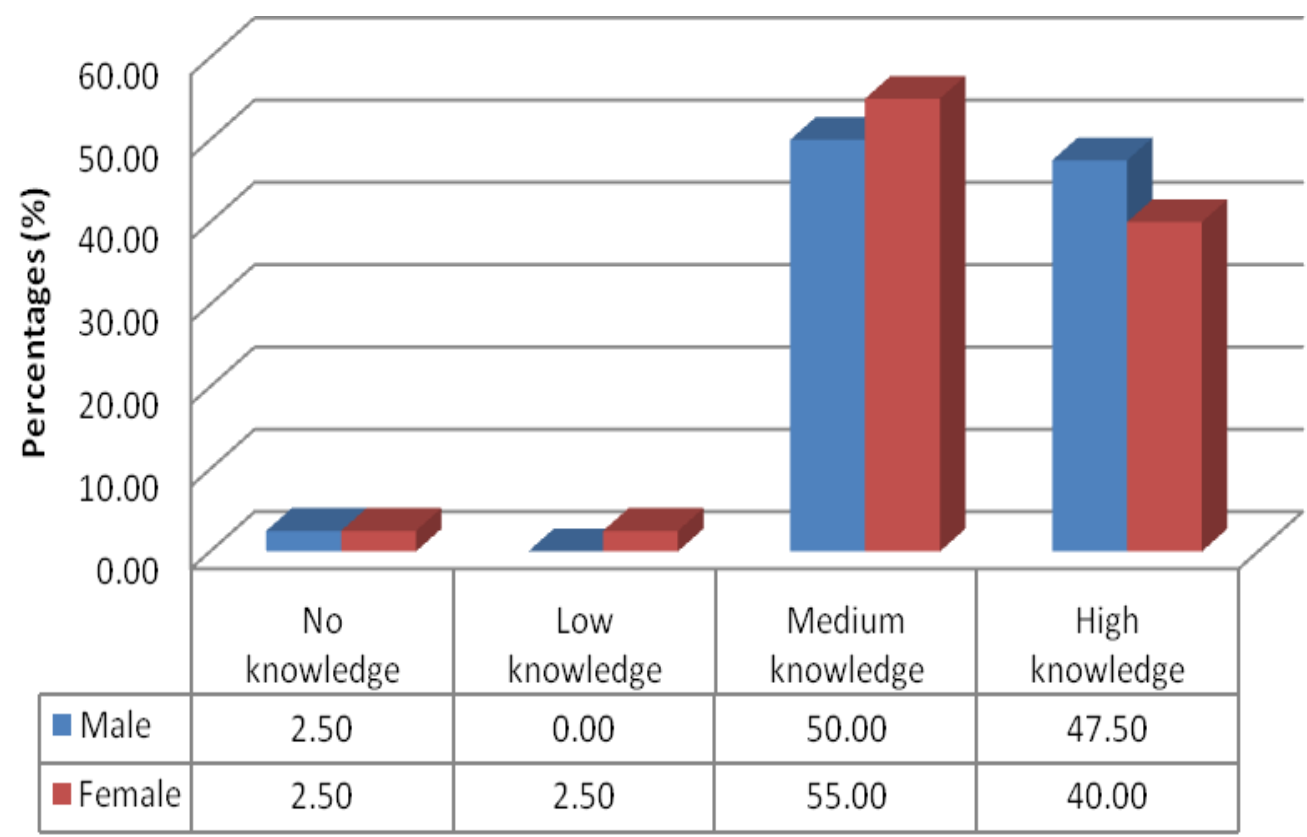

Figure 1: Knowledge level of climate change on livestock production by gender

\section{Extent of use of sources of information}

Table 3 indicates that both male and female livestock farmers in the study area did not effectively use the various sources through which information on climate change could be made available to them. This has serious implications on the level of knowledge respondents will have on recent trends about climate change and likewise hinder effective adaptation strategies by farmers. Okoro (2012) in his study found that the majority of farmers' information on climate change was by personal observation. Climate change and its uncertainties demand that farmers have regular access to new knowledge. It also entails farmers harnessing these various sources of knowledge to improve adaptation practices. According to Maponya and Mpandeli (2013), the odds of being affected by climate change is 2.46 times higher for farmers who did not receive information through extension services than those who did receive information through extension services. 
Creative commons User License: CC BY-NC-ND

Abstracted by: EBSCOhost, Electronic Journals Service (EJS),

Google Scholar, Directory of Open Access Journals (DOAJ),

Journal Seek, Scientific Commons,

Food and Agricultural Organization (FAO), CABI and Scopus
Journal of Agricultural Extension

Vol. XX (X) XXXXXX, 20XX

ISSN(e): 24086851; ISSN(Print); 1119944X

http://journal.aesonnigeria.org

http://www.ajol.info/index.php/iae

Email: editorinchief@aesonnigeria.org

Table 3: Extent of use of sources of information

\begin{tabular}{lcccc}
\hline Information source & Mean & $\begin{array}{c}\text { Male } \\
\text { Standard } \\
\text { deviation }\end{array}$ & Mean & $\begin{array}{c}\text { Female } \\
\text { Standard } \\
\text { deviation }\end{array}$ \\
\hline Extension agents & 0.46 & 0.505 & 0.36 & 0.489 \\
Community leaders & 0.46 & 0.505 & 0.36 & 0.489 \\
Research institute & 1.00 & 1.213 & 0.48 & 0.795 \\
Radio & 0.91 & 1.147 & 0.61 & 0.966 \\
Fellow farmers & 0.51 & 0.650 & 0.42 & 0.663 \\
Religious organizations & 0.66 & 0.765 & 0.36 & 0.489 \\
Print media & 0.46 & 0.505 & 0.36 & 0.489 \\
Mobile phone & 0.46 & 0.505 & 0.36 & 0.489 \\
Internet & 0.46 & 0.505 & 0.42 & 0.663 \\
NGOs & 0.46 & 0.505 & 0.36 & 0.489 \\
Fadama & 0.46 & 0.505 & 0.36 & 0.489 \\
Cooperative society & 0.66 & 0.873 & 0.36 & 0.489 \\
Veterinary office & 0.51 & 0.658 & 0.64 & 0.962 \\
Television & 0.46 & 0.505 & 0.36 & 0.489 \\
\hline
\end{tabular}

\section{Gender differences on information sourced on climate change}

Table 4 shows that more of the male respondents sourced information on where to sell their livestock $(97.1 \%)$, how to indicate when livestock is sick $(97.1 \%)$, how to keep livestock house clean (88.6\%) and how to control heat intensity through changing the style of animal house (82.9\%) compared to the female respondents. However, more of the female respondents sourced information on where to sell their livestock (100.0\%), sought information about how to prepare hay for livestock, how 
Creative commons User License: CC BY-NC-ND

Abstracted by: EBSCOhost, Electronic Journals Service (EJS), Google Scholar, Directory of Open Access Journals (DOAJ), Journal Seek, Scientific Commons,

Food and Agricultural Organization (FAO), CABI and Scopus
Journal of Agricultural Extension

Vol. XX (X) XXXXXX, 20XX

ISSN(e): 24086851; ISSN(Print); 1119944X

http://journal.aesonnigeria.org

http://www.ajol.info/index.php/jae

Email: editorinchief@aesonnigeria.org

to practice artificial insemination and feeding livestock with fodder/green fodder with 11.4 percent respectively compared to the male respondents. Meanwhile, none of the females sought information on how to raise animal either for diary, beef or breeding in comparison with the male respondents.

From the foregoing, it is clear that both males and females have profit making as a target hence the need for market information. In Africa, the marketing of agricultural products typically suffers from limited institutional support (ILRI (International Livestock Research Institute), (1995). Increase in heat intensity has negative effect on livestock production. Houghton et al. (2001) concluded that direct effects from air temperature, humidity, wind speed and other climate factors influence animal performance: growth, milk production, wool production and reproduction. Heat distress on animals will reduce the rate of animal feed intake and causes poor performance growth (Rowlinson, 2008).

\section{Table 4: Gender differences on information sourced on climate change}

\begin{tabular}{lll}
\hline Information sourced & Male (\%) & Female (\%) \\
\hline Knowledge on how to control heat intensity through changing the & 82.9 & 72.7 \\
style of animal houses & & \\
Method of livestock vaccination & 71.4 & 48.5 \\
Information on access to credit & 65.7 & 39.4 \\
Information on how to indicate when the livestock is sick & 97.1 & 97.0 \\
Information on how to keep animals with high resistant ability & 42.9 & 27.3 \\
Information on feed formulation & 62.9 & 33.3 \\
Information on where to sell the livestock & 97.1 & 100.0 \\
Knowledge on government policy regulation & 20.0 & 6.1 \\
Information to know when there is disease outbreak & 77.1 & 75.8 \\
Information on how to prepare hay for livestock & 11.4 & 18.2 \\
Knowledge on how to keep livestock house clean & 88.6 & 81.8 \\
Knowledge on how to keep record & 42.9 & 33.3 \\
Knowledge on how to crossbreed livestock & 14.3 & 9.1 \\
Knowledge on how to raise animal either for diary, beef or breeding & 28.6 & - \\
Knowledge on how to practice artificial insemination & 11.4 & 12.1 \\
Information on where and how to get animal drug & 77.1 & 60.6 \\
Knowledge on feeding livestock with fodder/green fodder & 11.4 & 18.2 \\
\hline
\end{tabular}


Creative commons User License: CC BY-NC-ND

Abstracted by: EBSCOhost, Electronic Journals Service (EJS),

Google Scholar, Directory of Open Access Journals (DOAJ),

Journal Seek, Scientific Commons,

Food and Agricultural Organization (FAO), CABI and Scopus
Journal of Agricultural Extension

Vol. XX (X) XXXXXX, 20XX

ISSN(e): 24086851; ISSN(Print); 1119944X

http://journal.aesonnigeria.org

http://www.ajol.info/index.php/jae

Email: editorinchief@aesonnigeria.org

\section{Difference between male and female's knowledge score on climate change}

Table 5 shows that there was no significant difference between male and female's knowledge scores on climate change. Climate change is a natural occurrence and can easily be identified even without being told or informed. This result contrasts sharply with the findings of Agwu and Okhimamhe (2009), Ekpo and Ekpo (2011), and Raudsepp (2011). Ekpo and Ekpo (2011) argued that the level of climate change knowledge varied with gender. However, they did not specify who have the greater knowledge. Agwu and Okhimamhe (2009) and Raudsepp (2011) submitted that women are found more knowledgeable than their male counterparts of the same age bracket. Raudsepp (2011) hinted that the common reason advanced for gender differences regarding climate change knowledge is the pattern of assignment of social responsibilities between boys and girls. The girls are assigned all the sweeping and cleaning activities and they gradually and unconsciously get so used to the welfare of the environment unlike their male counterpart.

Table 5: Difference between men and women's knowledge of climate change

\begin{tabular}{lccccc}
\hline & Mean & $\begin{array}{l}\text { Male } \\
\text { Standard } \\
\text { deviation }\end{array}$ & Mean & $\begin{array}{l}\text { Standard } \\
\text { deviation }\end{array}$ & $\mathrm{t}$ \\
\hline $\begin{array}{l}\text { Knowledge } \\
\text { score }\end{array}$ & 13.92 & 13.92 & 13.20 & 3.406 & 0.971 \\
\hline
\end{tabular}

Source: Field survey, 2014

\section{Conclusion and Recommendations}

Men and women livestock producers in the study had knowledge on climate change. Marketing information was vital in the information sourced for by respondents. Livestock production relies on stable markets to thrive. Therefore, increased access to marketing information would improve the economic situation of farmers thus alleviating poverty. More training and enlightenment campaigns should be conducted by the state government in close partnership with stakeholders (with special reference to extension agencies) in the agricultural sector to sustain and improve the 
Creative commons User License: CC BY-NC-ND

Abstracted by: EBSCOhost, Electronic Journals Service (EJS),

Google Scholar, Directory of Open Access Journals (DOAJ),

Journal Seek, Scientific Commons,

Food and Agricultural Organization (FAO), CABI and Scopus
Journal of Agricultural Extension

Vol. XX (X) XXXXXX, 20XX

ISSN(e): 24086851; ISSN(Print); 1119944X

http://journal.aesonnigeria.org

http://www.ajol.info/index.php/jae

Email: editorinchief@aesonnigeria.org

existing knowledge base for both men and women livestock producers in the study area. This will also include, encouraging both men and women livestock producers to seek for information from approved channels to further help curtail the negative impact of climate change on livestock production.

\section{References}

Agwu, J. \& Okhimamhe, A. A. (2009). Gender and climate change in Nigeria: A study of four communities in North-Central and South-Eastern Nigeria. Lagos: Heinrich Böll Stiftung.

Anyadike, R.N.C. (2009). Climate change and sustainable development in Nigeria: Conceptual and empirical issues. Enugu forum policy paper 10. African Institute for Applied Economics, Nigeria.

Calvosa: C. Delgerma: C, and Katiuscia, F. (2009). Livestock and climate change. International Fund for Agricultural Development. http://www.ifad.org.

Deressa M.J., Hassan S. (2009). An analysis of technical efficiency of livestock formers in the mixed farming system of the Punjab (Ph.D thesis) Department of Environmental and Resources Economics (farm management) University of Agriculture, Fasialabad

Egbule, C.L. (2014). Gender vulnerability and adaptation strategies to climate change impacts on agriculture in the Niger Delta Region of Nigeria (Ph.D. Thesis). Department of Agricultural Extension, University of Nigeria, Nsukka, Enugu State, Nigeria.

Ekpo, U. I. \& Ekpo, J. I. (2011). Assessing the level of climate change awareness among secondary school teachers in Calabar municipality, Nigeria: Implication for management effectiveness. Retrieved March 192012 from http://www.ijhssnet.com/journals/Vol. 1 No. 3; March 2011/16.pdf.

Enejeta, E. (2016). Agricultural sector contribution to GDP now at $24.18 \%$ - CBN. Financial Watch, 14 ${ }^{\text {th }}$ April, 2016.

Houghton, J.T., Ding Y., Griggs, D.J., Noguer M., van der Linden P.J, Dai X, Maskell K, Johnson C.A. (2001). Climate change: The scientific basis. Contribution of working group I to the third assessment report of the Intergovernmental Panel on Climate Change. New York: Cambridge University Press.

http://ww.undp.org/climatechange/adapt/basic3html

International Livestock Research Institute (ILRI). (1995). Livestock Policy Analysis. ILRI Training Manual 2. ILRI, Nairobi, Kenya. pp. 264. ISBN 92-9146-003-6

IPCC (2007). Fourth assessment report. Institute for applied economics (AIAE); Enugu Nigeria: 19-32. Available online at: 
Creative commons User License: CC BY-NC-ND

Abstracted by: EBSCOhost, Electronic Journals Service (EJS),

Google Scholar, Directory of Open Access Journals (DOAJ),

Journal Seek, Scientific Commons,

Food and Agricultural Organization (FAO), CABI and Scopus
Journal of Agricultural Extension

Vol. XX (X) XXXXXX, 20XX

ISSN(e): 24086851; ISSN(Print); 1119944X

http://journal.aesonnigeria.org

http://www.ajol.info/index.php/jae

Email: editorinchief@aesonnigeria.org

http://www.aiaenigeria.org/Publications/Policypaper10.pdf $\quad$ (Accessed $14^{\text {th }}$ November, 2009).

Issa, F.O., Tologbonse, B.E., Olaleye, R., Tologbonse, O.M. \& Kagbu, J.H. (2015). Farmers' perception of climate change and coping strategies across gender in two agro-ecological zones of Nigeria. Journal of Agricultural Extension, vol. 19(1): 1-15.

Maponya, P. and Mpandeli, S. (2013). The role of extension services in climate change adaptation in Limpopo province, South Africa. Journal of Agricultural Extension and Rural Development, vol. 5(7):137-142.

Nnadi, F.N., Umunakwe, P.C., Nnadi, C.D. \& Okafor, O.E. (2012). Socioeconomic determinants of farmers' use of ethnoveterinary medicine in Mbaitoli Local Government Area of Imo State, Nigeria. Rsch. Journal of Agri. \& Envi. Management, 1(1): 025-033.

Nwagwu, W.E. \& Soremi, O. (2015). ICT use in livestock innovation chain in lbadan City in Nigeria. Advances in Life Science and Technology, vol. 32:1-16.

Okolo C.A. (2004). Measuring profit efficiency using behavioural and stochastic frontier approaches. Appl. Econ. 26: 181-188.

Okoro, J. C. (2012). Climate change information needs of rural farmer in Enugu State, Nigeria. (M.Sc. Thesis). University of Nigeria, Nsukka, Enugu State, Nigeria.

Olaniyi, O. A., and Raufu, M. O. (2004). Youth Participation in Rural Development: A Case Study of Youth Programmes in Lagelu Local Government Area of Oyo State. Science Focus, vol. 9: 116-120.

Onyeneke, R.U. and Madukwe, D.K. (2010). Adaptation measures by crop farmers in the Southeast Rainforest Zone of Nigeria to Climate Change. Sci. World Journal, 5(1): 32-34.

Ozor, N. (2009). Understanding climate change. Implications for Nigerian agriculture, policy and extension. Paper presented at the National conference on climate change and the Nigeria Environment. Organized by the Department of Geography, University of Nigeria, Nsukka. 29 June-2 ${ }^{\text {nd }}$ July.

Ozor, N. and Nnaji, C. (2010). Difficulties in adaptation to climate change by farmers in Enugu State, Nigeria. Journal of Agricultural Extension, Vol. 144 (2): 106122.

Ozor, N., Umunakwe, P.C., Ani, A.O. and Nnadi, F.N. (2015). Perceived impacts of climate change among rural farmers in Imo State, Nigeria. African Journal of Agricultural Research, vol. 10(4), pp. 1756-1764.

Raudsepp, M. (2001). Some socio-demographic and socio-psychological predictors of environmentalism. TRAME, 5 (4), 355-367. 
Creative commons User License: CC BY-NC-ND

Abstracted by: EBSCOhost, Electronic Journals Service (EJS),

Google Scholar, Directory of Open Access Journals (DOAJ),

Journal Seek, Scientific Commons,

Food and Agricultural Organization (FAO), CABI and Scopus
Journal of Agricultural Extension

Vol. XX (X) XXXXXX, 20XX

ISSN(e): 24086851; ISSN(Print); 1119944X

http://journal.aesonnigeria.org

http://www.ajol.info/index.php/jae

Email: editorinchief@aesonnigeria.org

Rowlinson, P., (2008). Adaptation Livestock Production Systems to Climate ChangeTemperate Zones. Livestock and global change conference proceeding. May 2008, Tunisia.

Smith, K., (2007). Environmental hazards: assessing risk and reducing disaster. (3rd edition). London: Routledge.

Tailor G.T., Negada J.J. (2005). Adaptive capacity and human cognition: the process of individual adaptation to climate change. Global Environ. Chang 15, 199213.

Upadhya, H.M., El-marasatawy, S.M. and Ouda, S.A. (2009). Socio-economic analysis of cattle production, implication input use. India. J. Hort Sci 6 (1):4043.

World Bank (2009). Minding the stock. Bringing public policy to bear on livestock sector development. Report No. 44010-GLB. The World Bank, Washington D.C., US.A. 